Article

\title{
Investigations of Metal Pollution in Road Dust of Steel Industrial Area and Application of Magnetic Separation
}

\author{
Hyeryeong Jeong ${ }^{1,2}\left[\right.$ and Kongtae $\mathrm{Ra}^{1,2, *}$
}

1 Marine Environmental Research Center, Korea Institute of Ocean Science and Technology (KIOST), Busan 49111, Korea; hrjeong@kiost.ac.kr

2 Department of Ocean Science (Oceanography), KIOST School, University of Science and Technology (UST), Daejeon 34113, Korea

* Correspondence: ktra@kiost.ac.kr

check for

updates

Citation: Jeong, H.; Ra, K.

Investigations of Metal Pollution in Road Dust of Steel Industrial Area and Application of Magnetic Separation. Sustainability 2022, 14, 919. https://doi.org/10.3390/ su14020919

Academic Editors: Jose Navarro Pedreño, Antonis A. Zorpas and I. Gómez Lucas

Received: 23 December 2021

Accepted: 12 January 2022

Published: 14 January 2022

Publisher's Note: MDPI stays neutral with regard to jurisdictional claims in published maps and institutional affiliations.

Copyright: () 2022 by the authors Licensee MDPI, Basel, Switzerland. This article is an open access article distributed under the terms and conditions of the Creative Commons Attribution (CC BY) license (https:// creativecommons.org/licenses/by/ $4.0 /)$.

\begin{abstract}
Pollution characteristics and ecological risks for metals in non-magnetic and magnetic road dust from steel industrial areas were investigated by applying a magnetic separation method. Metal (except for $\mathrm{Al}, \mathrm{Li}, \mathrm{Ti}, \mathrm{As}$, and $\mathrm{Sb}$ ) concentrations in the magnetic road dust were $1.2(\mathrm{Sn})$ to $7.8(\mathrm{Fe})$ times higher than those in the non-magnetic road dust. For the magnetic road dust, the geo-accumulation index revealed a strongly to extremely polluted status for $\mathrm{Cr}, \mathrm{Zn}, \mathrm{Cd}$, and $\mathrm{Sb}$, a strongly polluted status for $\mathrm{Mn}, \mathrm{Cu}$, and $\mathrm{Pb}$, and a moderately to strongly polluted status for $\mathrm{Fe}, \mathrm{Ni}, \mathrm{Mo}$, and $\mathrm{Hg}$. This result indicates that the dominant metal pollution sources of road dust in industrial areas were the traffic activities of heavy-duty vehicles. The mean content of magnetic particles accounted for $44.7 \%$ of the total road dust. The metal loadings in the magnetic road dust were $86 \%(\mathrm{Fe}), 77 \%(\mathrm{Cr}), 67 \%(\mathrm{Mn})$, $86 \%(\mathrm{Ni}), 76 \%(\mathrm{Cu}), 72 \%(\mathrm{Zn}), 64 \%(\mathrm{Mo})$, and $62 \%(\mathrm{Cd})$, respectively. Removal of the magnetic fraction from road dust using magnetic separation techniques not only reduces metal contamination but can also improve effective road cleaning strategies or reduce waste generation.
\end{abstract}

Keywords: magnetic separation; metal pollution; road dust; road cleaning strategy

\section{Introduction}

Metal elements in soil and sediments are released into the environment by the weathering of bedrock and anthropogenic activities. These metals exist in various chemical forms, such as carbonate minerals and oxide minerals, and are adsorbed on the surface of particles and bound with organic matter. Magnetic properties are one of the major physical properties of rocks, soils, and sediments, and are widely used in geological and environmental studies, such as the determination of past climates and the origin of sediments [1-3]. Because some metal elements have a high correlation with magnetic susceptibility and behave with Fe-Mn oxides, these properties are actively used in environmental research, such as tracing the origin of metal contamination in the environment and the treatment of metal contamination in water and soil [4-9]. Magnetic separation is a technology that effectively separates magnetic particles. It is also used in the recycling of ferrous, non-ferrous, and rare metals from industrial wastes and slags generated from industrial activities such as mining, smelting, and steel manufacturing processes [10-14].

Road dust is an important reservoir of metals emitted in urban environments by traffic and industrial activities, and it is also a source of metal contamination to the surrounding water, soil, and atmospheric environments through stormwater runoff and fugitive dust [15-19]. Road dust contains Fe-rich particles derived from the wear/corrosion of engine and vehicle bodies, as well as tire and brake pad wear [20-22]. It has been reported that magnetic particles are strongly correlated with some metals [23-26]. The pollution status of metals in road dust depends on the particle size, with fine particles being more contaminated with metals [27]. Fine particles in road dust are easily resuspended into the atmospheric environment. Exposure to metals through the inhalation of fine particles with 
high metal concentrations can have a harmful effect on the human body and increase the metal concentration in the body [28-32]. Many studies have been conducted to assess the degree of metal contamination in road dust and to identify the contamination sources and harmful effects on human health [33-39]. Because road dust is one of the pollution hotspots of toxic metals in urban environments, it can lead to atmospheric pollution and have a harmful effect on human health.

Road cleaning can effectively remove road dust contaminated with metals; therefore, a variety of road sweepers are used in many countries to remove road dust [40-49]. Road dust removed from the road surface contains high concentrations of hazardous metals and is classified as waste; therefore, it causes another environmental issue by generating waste from a huge amount of road dust removed through road cleaning. However, the research on road dust and metal loading accumulated on the road surface is insufficient. Therefore, in the present study, the applicability of magnetic separation to reduce the metal contamination of road dust was investigated by evaluating the degree of contamination of 18 metals, the metal loadings on the road surface for each metal, and the relative contributions of metals in magnetic and non-magnetic road dust.

\section{Materials and Methods}

\subsection{Sampling}

Road dust samples were collected in December 2013 using a vacuum suction cleaner (DC-35; Dyson, Malmesbury, UK) at 19 sites within the Pohang industrial area (Figure 1). Road dust sampling sites were selected around the entrances and exits to major industrial facilities to evaluate metal contamination from industrial activity. In the Pohang industrial area, the largest domestic steel companies, such as POSCO and Hyundai steel plants exist, and 359 companies operate in five steel-related industrial complexes. There was a 9-day antecedent dry period before collecting the road dust samples, and careful attention was paid to securing the representativeness of each sample and preventing cross-contamination among samples. A 4000-gauss hand magnet was sealed in a propylene bag, and about $100 \mathrm{~g}$ of oven-dried samples were separated several times until no magnetic particles were attached to the magnet. After measuring the weight $(\mathrm{g})$ of the separated magnetic and nonmagnetic particles, the total mass of road dust $\left(\mathrm{g} / \mathrm{m}^{2}\right)$ in each fraction was calculated. The road dust samples separated into magnetic and non-magnetic particles were pulverized and homogenized with an automatic agate mortar (Pulverisette 6; Fritsch Co., Idar-Oberstein, Germany) and stored in an acid-cleaned polyethylene bottle prior to the metal analysis.

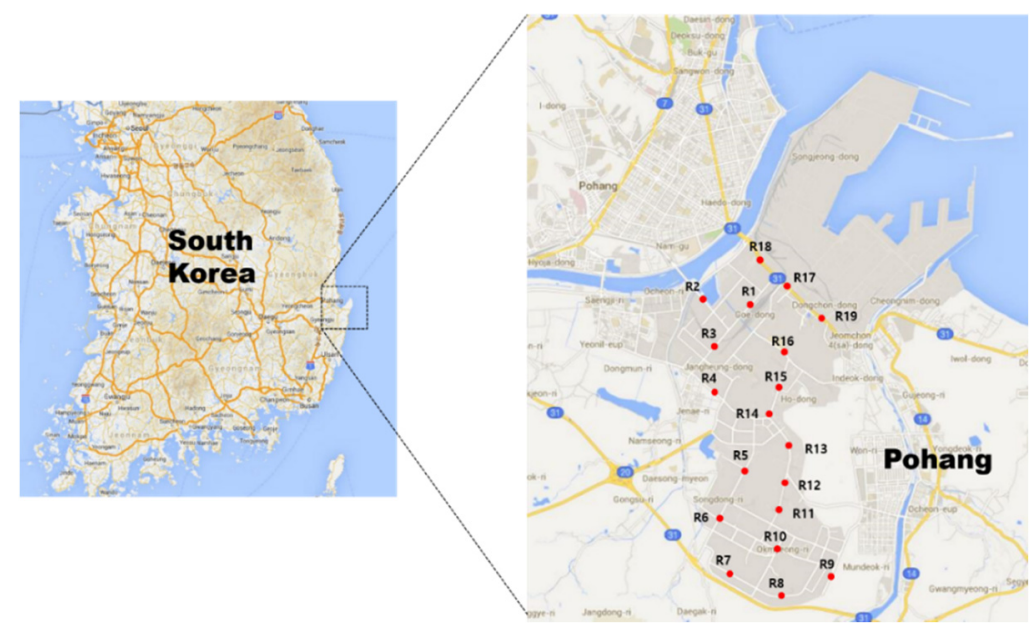

Figure 1. Sampling sites for road dust (RD) from the Pohang steel Industrial regions, South Korea (base map from Google Earth). 


\subsection{Metal Analysis}

About $0.1 \mathrm{~g}$ of the homogenized road dust sample was placed in a Savillex Teflon digestion vessel. A mixture of high-purity acids $\left(\mathrm{HF}, \mathrm{HNO}_{3}\right.$, and $\left.\mathrm{HClO}_{4}\right)$ was added, and the sample was completely decomposed at $180^{\circ} \mathrm{C}$ on a hot plate. Seventeen metal elements ( $\mathrm{Al}, \mathrm{Fe}, \mathrm{Li}, \mathrm{Ti}, \mathrm{V}, \mathrm{Cr}, \mathrm{Mn}, \mathrm{Co}, \mathrm{Ni}, \mathrm{Cu}, \mathrm{Zn}, \mathrm{As}, \mathrm{Mo}, \mathrm{Cd}, \mathrm{Sn}, \mathrm{Sb}$, and $\mathrm{Pb}$ ) were analyzed using inductively coupled plasma mass spectrometry (ICP-MS; iCAP-Q, Thermo Scientific Co., Bremen, Germany). An automated analyzer (Hydra-C; Teledyne Technology Co., Thousand Oaks, CA, USA) was used to analyze the Hg based on the US EPA 7473 method. To verify the accuracy of the metal analysis, the MESS-4, which has the largest number of certified values for metals, and the BCR-723 certified reference materials for road dust, were pre-treated and analyzed with the sample. The recoveries were $94.9-104.1 \%$ for MESS-4 and $98.0-103.7 \%$ for BCR-723.

\subsection{Pollution and Ecological Risk Assessment}

The geo-accumulation index ( $\mathrm{I}_{\text {geo }}$ ) was calculated to evaluate the individual contamination level of each metal using the following equation [50,51]:

$$
\mathrm{I}_{\text {geo }}=\log _{2}\left(C_{\mathrm{n}} / 1.5 \times \mathrm{B}_{\mathrm{n}}\right)
$$

where $C_{n}$ and $B_{n}$ represent the metal concentrations in road dust and the upper crust [52] respectively, and a factor of 1.5 was used to correct for the influence of a crustal origin. Igeo values fall into seven categories: $\mathrm{I}_{\text {geo }}>5$ (extremely polluted), $4<\mathrm{I}_{\text {geo }}<5$ (strongly to extremely polluted), $3<\mathrm{I}_{\text {geo }}<4$ (strongly polluted), $2<\mathrm{I}_{\text {geo }}<3$ (moderately to strongly polluted), $1<\mathrm{I}_{\text {geo }}<2$ (moderately polluted), $1<\mathrm{I}_{\text {geo }}<2$ (unpolluted to moderately polluted), and $\mathrm{I}_{\text {geo }}<0$ (uncontaminated).

The individual ecological risk degree $\left(\mathrm{E}_{\mathrm{r}}^{\mathrm{i}}\right)$ and potential ecological risk index (PERI) for the 13 metal elements with toxic response factors were calculated using the following equations [53]:

$$
\begin{gathered}
\mathrm{E}_{\mathrm{r}}^{\mathrm{i}}=\mathrm{T}_{\mathrm{r}}^{\mathrm{i}} \times\left(\mathrm{C}_{\mathrm{n}} / \mathrm{B}_{\mathrm{n}}\right) \\
\text { PERI }=\sum_{\mathrm{i}}^{\mathrm{n}} \mathrm{E}_{\mathrm{r}}^{\mathrm{i}}
\end{gathered}
$$

where $C_{n}$ and $B_{n}$ are equivalent to the $I_{\text {geo }}$ calculation and $T_{r}^{i}$ represents a toxic response factor $(\mathrm{Hg}=40, \mathrm{Cd}=30, \mathrm{As}=10, \mathrm{Sb}=7, \mathrm{Co}=\mathrm{Cu}=\mathrm{Ni}=\mathrm{Pb}=5, \mathrm{~V}=\mathrm{Cr}=2, \mathrm{Ti}=\mathrm{Mn}=\mathrm{Zn}=1)$ [53-55].

The $\mathrm{E}_{\mathrm{r}}^{\mathrm{i}}$ values were classified into five classes: $\mathrm{E}_{\mathrm{r}}^{\mathrm{i}}>320$ (extreme risk), $160<\mathrm{E}_{\mathrm{r}}^{\mathrm{i}}<320$ (high risk), $80<\mathrm{E}_{\mathrm{r}}^{\mathrm{i}}<160$ (considerable risk), $40<\mathrm{E}_{\mathrm{r}}^{\mathrm{i}}<80$ (moderate risk), and $\mathrm{E}_{\mathrm{r}}^{\mathrm{i}}<40$ (low risk). The PERI values were classified into four grades: PERI $>600$ (high risk), $300<$ PERI $<600$ (considerable risk), $150<$ PERI < 300 (moderate risk), and PERI < 150 (low risk).

\subsection{Estimation of the Metal Loading in Magnetic and Non-Magnetic Road Dust}

The relative mass loading percentage $\left(\mathrm{P}_{\mathrm{i}} ; \%\right)$ for the magnetic and non-magnetic road dust was calculated using the following equation:

$$
\text { Mass loading } \text { magnetic road dust }(\%)=\left[\frac{\mathrm{W}_{\mathrm{MP}}}{\mathrm{W}_{\mathrm{MP}}+\mathrm{W}_{\mathrm{NMP}}}\right] \times 100
$$

Mass loading $_{\text {non-magnetic road dust }}(\%)=100$ - Mass loading magnetic road dust

where $\mathrm{W}_{\mathrm{MP}}$ and $\mathrm{W}_{\mathrm{NMP}}$ is the weight of the magnetic (MP) and non-magnetic particles (NMP) separated from each road dust sample. 
The relative metal loading percentage (\%) for each metal in the magnetic and nonmagnetic road dust was calculated using the following equation:

$$
\text { Metal loading }(\%)=\left[\frac{\mathrm{C}_{n} \times \mathrm{P}_{\mathrm{i}}}{\sum_{\mathrm{i}=1}^{2} \mathrm{C}_{\mathrm{n}} \times \mathrm{P}_{\mathrm{i}}}\right] \times 100
$$

where $C_{n}$ is the concentration of each metal in the magnetic and non-magnetic particles, and $P_{i}$ is the mass percentage of two different portions of road dust. The sum of the metal loading percentage values for the magnetic and non-magnetic fractions is always 100\%. The loading values of road dust and metals in the magnetic and non-magnetic portions were expressed as $\mathrm{g} / \mathrm{m}^{2}$ and $\mathrm{mg} / \mathrm{m}^{2}$, respectively, by dividing the total sampling area of road dust $\left(\mathrm{m}^{2}\right)$.

\section{Results and Discussion}

\subsection{Metal Concentrations in Magnetic and Non-Magnetic Road Dust}

The average concentrations of the 18 metal elements in the magnetic road dust followed the descending order of $\mathrm{Fe}>\mathrm{Al}>\mathrm{Mn}>\mathrm{Cr}>\mathrm{Ti}>\mathrm{Zn}>\mathrm{Cu}>\mathrm{Pb}>\mathrm{Ni}>\mathrm{V}>\mathrm{Co}>$ $\mathrm{Li}>\mathrm{Mo}>\mathrm{Sb}>\mathrm{Sn}>\mathrm{As}>\mathrm{Cd}>\mathrm{Hg}$ (Table 1 and Figure 2). The values of the coefficient of variation ( $\mathrm{CV}$; \%) of $\mathrm{Co}, \mathrm{As}, \mathrm{Pb}$, and $\mathrm{Hg}$ in the magnetic road dust exceeded 100, indicating that the differences in the concentrations of these metals were largely dependent on the sampling site. However, the CV values of $\mathrm{Al}, \mathrm{Fe}, \mathrm{Li}$, and $\mathrm{Ti}$ ranged from 12 to $24 \%$, indicating that the differences in their concentrations in road dust were not significant.
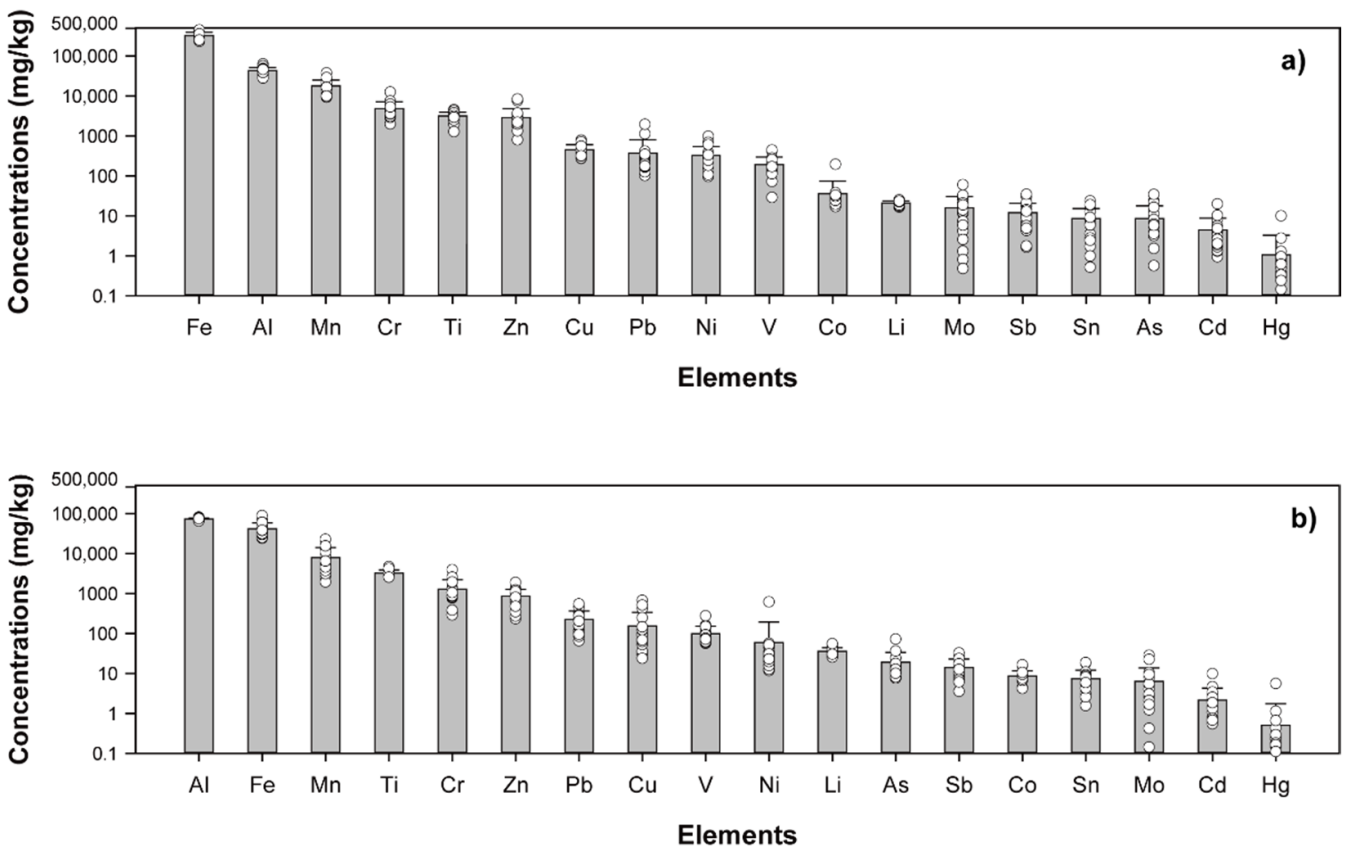

Figure 2. Comparison of mean concentrations of 18 metals in magnetic (a), and non-magnetic (b) road dust from steel industrial region of Korea.

The mean Fe concentration in the magnetic road dust was 32.5\% (range: $22.9-44.3 \%$ ) (Table 1). Fe was the dominant metal, accounting for $71-90 \%$ of the metal mass load. In urban environments, Fe-rich magnetic particles in road dust are emitted from vehicles through the wear and corrosion of vehicle engines and bodies as well as exhaust emissions $[24,56]$. In this study, the Fe concentration in the magnetic road dust was very high compared to road dust in urban areas $[57,58]$. Industrial facilities involved in steel smelting, production, and processing are concentrated around the study area. The main sources of Fe are because iron ore raw material storage sites and metal particles released from the processing inside industrial facilities are diffused into road dust by the wind. In steel 
production, compounds such as ferromanganese (FeMn) and ferrosilicon (FeSi) are added to remove excess oxygen [59]. The average Mn concentration in the magnetic road dust was $17,847 \mathrm{mg} / \mathrm{kg}$, which is the third-highest concentration after Fe and Al.

The mean $\mathrm{Cr}$ and Ni concentrations were 4788 and $328 \mathrm{mg} / \mathrm{kg}$. There is a good correlation between these two metals $(\mathrm{r}=0.61)$, but there is no correlation with other metals (Table S1). The mean $\mathrm{Zn}, \mathrm{Cu}, \mathrm{Pb}, \mathrm{Sb}$, and $\mathrm{Sb}$ concentrations were 2885, 452, 371, 11.9, and $8.6 \mathrm{mg} / \mathrm{kg}$, respectively. The $\mathrm{Zn}, \mathrm{Cu}$, and $\mathrm{Pb}$ concentrations in the magnetic road dust in this study were higher than those in urban road dust, but the $\mathrm{Sb}$ and $\mathrm{Sn}$ concentrations were relatively low compared to the reported urban road dust concentrations in Korea [18]. There are statistically significant correlations among these metals (Table S1), indicating that the contamination of $\mathrm{Zn}, \mathrm{Cu}, \mathrm{Pb}, \mathrm{Sb}$, and $\mathrm{Sn}$ was highly affected by traffic activities related to non-exhaust emissions, such as the wear of brake pads and tires [60].

Table 1. Comparison of minimum, maximum, mean, and coefficient of variation (CV) values for 18 metal concentrations in the magnetic and non-magnetic road dust of this study.

\begin{tabular}{|c|c|c|c|c|c|c|c|c|c|c|c|c|c|c|c|c|c|c|}
\hline & Al & $\mathrm{Fe}$ & $\mathrm{Li}$ & $\mathrm{Ti}$ & $\mathbf{V}$ & $\mathrm{Cr}$ & Mn & Co & $\mathrm{Ni}$ & $\begin{array}{c}\mathrm{Cu} \\
\mathrm{mg}\end{array}$ & $\mathrm{g}^{\mathrm{Zn}}$ & As & Mo & $\mathrm{Cd}$ & Sn & $\mathrm{Sb}$ & $\mathrm{Pb}$ & $\mathrm{Hg}$ \\
\hline \multicolumn{19}{|c|}{ Magnetic road dust } \\
\hline Min & 2.8 & 22.9 & 16.4 & 1262 & 29 & 1963 & 9152 & 16.9 & 96 & 268 & 794 & 0.1 & 0.5 & 0.9 & 0.5 & 1.6 & 101 & 0.03 \\
\hline $\operatorname{Max}$ & 6.2 & 44.3 & 25.0 & 4487 & 441 & 12,367 & 37,292 & 194 & 970 & 779 & 8269 & 34.1 & 59.4 & 19.7 & 23.4 & 34.3 & 1930 & 10.0 \\
\hline Mean & 4.3 & 32.5 & 21.0 & 3143 & 194 & 4788 & 17,848 & 36.2 & 328 & 452 & 2885 & 8.6 & 15.8 & 4.5 & 8.6 & 11.9 & 371 & 1.1 \\
\hline St. Dev & 0.8 & 6.6 & 2.6 & 764 & 103 & 2388 & 7005 & 38.6 & 214 & 151 & 1889 & 9.1 & 14.4 & 4.4 & 6.7 & 9.0 & 437 & 2.2 \\
\hline CV $(\%)$ & 19 & 20 & 12 & 24 & 53 & 50 & 39 & 107 & 65 & 33 & 65 & 106 & 91 & 98 & 77 & 75 & 118 & 211 \\
\hline \multicolumn{19}{|c|}{ Non-magnetic road dust } \\
\hline Min & 6.4 & 2.4 & 25.4 & 2529 & 56.3 & 289 & 1938 & 4.2 & 11.7 & 23.7 & 232 & 7.5 & 0.1 & 0.5 & 1.6 & 3.5 & 65.4 & 0.02 \\
\hline Max & 8.1 & 8.8 & 55.2 & 4639 & 275 & 3919 & 22,500 & 16.3 & 614 & 672 & 1881 & 71.6 & 28.5 & 9.8 & 18.6 & 32.5 & 543 & 5.6 \\
\hline Mean & 7.3 & 4.2 & 36.2 & 3237 & 98.7 & 1293 & 7965 & 8.7 & 59.5 & 156 & 855 & 19.2 & 6.4 & 2.2 & 7.4 & 14.1 & 226 & 0.5 \\
\hline St. dev & 0.4 & 1.7 & 8.3 & 638 & 54.1 & 945 & 6119 & 3.1 & 135 & 180 & 410 & 14.5 & 7.4 & 2.2 & 4.7 & 9.0 & 144 & 1.3 \\
\hline CV $(\%)$ & 6 & 41 & 23 & 20 & 55 & 73 & 77 & 36 & 227 & 116 & 48 & 76 & 116 & 99 & 63 & 64 & 64 & 247 \\
\hline \multicolumn{19}{|c|}{ Background [52] and soil quality guideline value of Korea [61]. } \\
\hline Background & 8.2 & 3.9 & 21 & 3840 & 97 & 92 & 774 & 17.3 & 47 & 28 & 67 & 4.8 & 1.1 & 0.09 & 2.1 & 0.4 & 17 & 0.05 \\
\hline $\begin{array}{l}\text { Contamination } \\
\text { Guide value }\end{array}$ & & & & & & 40 & & & 500 & 2000 & 2000 & 200 & & & & & 700 & 20 \\
\hline \multicolumn{19}{|l|}{ Contamination } \\
\hline $\begin{array}{l}\text { Clean-up } \\
\text { value }\end{array}$ & & & & & & 120 & & & 1500 & 6000 & 5000 & 600 & & & & & 2100 & 60 \\
\hline
\end{tabular}

The $\mathrm{Cu}, \mathrm{As}, \mathrm{Cd}$, and $\mathrm{Hg}$ concentrations in the magnetic road dust were below the soil contamination guide values in Korea of 2000, 200, 60, and $20 \mathrm{mg} / \mathrm{kg}$, respectively [61]. High $\mathrm{Ni}, \mathrm{Zn}$, and $\mathrm{Pb}$ concentrations that exceeded the soil contamination guide values of 500,2000 , and $700 \mathrm{mg} / \mathrm{kg}$, respectively, were observed at three sites for $\mathrm{Ni}, 13$ sites for $\mathrm{Zn}$, and two sites for $\mathrm{Pb}$ among the 19 sampling sites. For $\mathrm{Zn}$, one sampling site exceeded the soil contamination clean-up value $(5000 \mathrm{mg} / \mathrm{kg})$ by 1.6 times.

In the non-magnetic road dust, the mean concentration of metals followed the descending order of $\mathrm{Al}>\mathrm{Fe}>\mathrm{Mn}>\mathrm{Ti}>\mathrm{Cr}>\mathrm{Zn}>\mathrm{Pb}>\mathrm{Cu}>\mathrm{V}>\mathrm{Ni}>\mathrm{Li}>\mathrm{As}>\mathrm{Sb}>\mathrm{Co}>\mathrm{Sn}$ $>\mathrm{Mo}>\mathrm{Cd}>\mathrm{Hg}$. The mean $\mathrm{CV}$ value of $\mathrm{Al}$, an element strongly related to particle size, was $6 \%$, indicating that most of the non-magnetic particles in road dust were uniformly affected by the surrounding soils. The $\mathrm{CV}$ values of $\mathrm{Ni}, \mathrm{Cu}, \mathrm{Mo}$, and $\mathrm{Hg}$ were greater than 100 , indicating that these metals were greatly affected by anthropogenic pollution around the sampling site. Of the 18 metals, $\mathrm{Al}$ had the highest concentrations in the non-magnetic road dust (Figure 2). The mean Fe concentration in the non-magnetic road dust was $4.17 \%$ (range: $2.38-8.88 \%$ ), which was $13 \%$ of the concentration in the magnetic road dust. Among the 18 metals, the mean metal loading of $\mathrm{Al}$ was $58 \%$, which was higher than that of the other metals. The mean metal loading of Fe in the road dust was $31 \%$, which was significantly lower than that in the magnetic road dust (81\%). There were higher mean $\mathrm{Al}$, $\mathrm{Li}$, As, and $\mathrm{Sb}$ concentrations in the non-magnetic road dust than in the magnetic road dust. $\mathrm{Al}$ and $\mathrm{Li}$ are affected by lithogenic and natural sources. Therefore, they may have different characteristics than other metals that are influenced by anthropogenic sources. The mean concentration of $\mathrm{Sb}$ was slightly higher in the non-magnetic fraction than the magnetic 
fraction, but they had almost similar values. A previous study reported that the As concentration in the non-magnetic fraction of road dust was higher than the magnetic fraction [26]. On the other hand, Jordanova et al. [62] reported that the As and Sb concentrations in the magnetic fraction of road dust were higher than in the non-magnetic fraction. There seems to be a difference in these metal concentrations depending on the study area. However, for most metal elements, the mean concentrations in the non-magnetic road dust were 13-61\% of the concentrations in the magnetic road dust (Table 1). The metal concentrations at all sampling sites were below the soil contamination guide values in Korea.

\subsection{Pollution and Ecological Risk Assessments}

In the magnetic road dust, $\mathrm{Cr}$ had the highest mean $\mathrm{I}_{\text {geo }}$ value of 4.98 . The $\mathrm{I}_{\text {geo }}$ values followed the descending order of $\mathrm{Cr}>\mathrm{Zn}>\mathrm{Cu}>\mathrm{Sb}>\mathrm{Mn}>\mathrm{Pb}>\mathrm{Cu}>\mathrm{Hg}>\mathrm{Mo}>\mathrm{Fe}>$ $\mathrm{Ni}>\mathrm{Sn}>\mathrm{V}>\mathrm{Co}>\mathrm{Li}>\mathrm{As}>\mathrm{Ti}>\mathrm{Al}$. The mean $\mathrm{I}_{\text {geo }}$ values of $\mathrm{Cr}, \mathrm{Zn}$, and Cd exceeded 4, indicating a strongly to extremely polluted status (Table 2). Among the 19 sampling sites, $\mathrm{Cr}$, $\mathrm{Zn}$, and $\mathrm{Cd}$ had $\mathrm{I}_{\text {geo }}$ values exceeding 5 at seven, four, and seven sampling sites, respectively. The $\mathrm{I}_{\text {geo }}$ values of $\mathrm{Mn}, \mathrm{Cu}$, and $\mathrm{Pb}$ were between 3 and 4, indicating a strongly polluted status, while $\mathrm{Pb}$ had $\mathrm{I}_{\text {geo }}$ values exceeding 5 (extremely polluted) at sites $\mathrm{R} 9$ and R10. The mean $\mathrm{I}_{\text {geo }}$ values of $\mathrm{Fe}, \mathrm{Ni}, \mathrm{Mo}$, and $\mathrm{Hg}$ were classified as moderately to strongly polluted.

Table 2. Comparison of mean $I_{g e o}$ values for 18 metals in magnetic and non-magnetic road dust from steel industrial areas.

\begin{tabular}{|c|c|c|c|c|c|c|}
\hline Types & $\mathrm{I}_{\text {geo }}<0$ & $0<\mathrm{I}_{\text {geo }}<1$ & $1<\mathrm{I}_{\text {geo }}<2$ & $2<\mathrm{I}_{\text {geo }}<3$ & $3<\mathrm{I}_{\text {geo }}<4$ & $4<\mathrm{I}_{\text {geo }}<5$ \\
\hline $\begin{array}{c}\text { Class } \\
\text { Magnetic road dust }\end{array}$ & $\begin{array}{l}\text { Unpolluted } \\
\mathrm{Al}, \mathrm{Li}, \mathrm{Ti}, \mathrm{As}\end{array}$ & $\begin{array}{c}\text { Unpolluted to } \\
\text { moderately polluted } \\
\text { V, Co, Sn }\end{array}$ & $\begin{array}{l}\text { Moderately } \\
\text { polluted }\end{array}$ & $\begin{array}{l}\text { Moderately to } \\
\text { strongly polluted } \\
\text { Fe, Ni, Mo, Hg }\end{array}$ & $\begin{array}{l}\text { Strongly } \\
\text { polluted } \\
\mathrm{Mn}, \mathrm{Cu}, \mathrm{Pb}\end{array}$ & $\begin{array}{l}\text { Strongly to } \\
\text { extremely polluted } \\
\mathrm{Cr}, \mathrm{Zn}, \mathrm{Cd}, \mathrm{Sb}\end{array}$ \\
\hline Non-magnetic road dust & $\mathrm{Al}, \mathrm{Fe}, \mathrm{Ti}, \mathrm{V}, \mathrm{Co}, \mathrm{Ni}$ & $\mathrm{Li}$ & $\begin{array}{c}\mathrm{Cu}, \mathrm{As}, \mathrm{Mo}, \mathrm{Sn}, \\
\mathrm{Hg}\end{array}$ & $\mathrm{Cr}, \mathrm{Mn}, \mathrm{Zn}, \mathrm{Pb}$ & $\mathrm{Cd}$ & $\mathrm{Sb}$ \\
\hline
\end{tabular}

In the non-magnetic road dust, $\mathrm{Sb}$ had the highest mean $\mathrm{I}_{\text {geo }}$ value of 4.28 . The $\mathrm{I}_{\text {geo }}$ values followed the descending order of $\mathrm{Sb}>\mathrm{Cd}>\mathrm{Zn}>\mathrm{Cr}>\mathrm{Pb}>\mathrm{Mn}>\mathrm{Cu}>\mathrm{As}>\mathrm{Hg}$ $>\mathrm{Mo}>\mathrm{Sn}>\mathrm{Li}>\mathrm{Fe}>\mathrm{V}>\mathrm{Al}>\mathrm{Ti}>\mathrm{Ni}>\mathrm{Co}$. The $\mathrm{I}_{\text {geo }}$ values for $\mathrm{Sb}$ and $\mathrm{Cd}$ indicated a strongly to extremely polluted and a strongly polluted status, respectively, and the $\mathrm{I}_{\text {geo }}$ value exceeded 5 at four and two sampling sites, respectively (Table 2). Cr, Mn, Zn, and Pb had strongly polluted statuses, although the pollution status was lower than that of the magnetic road dust. Meanwhile, $\mathrm{Cu}, \mathrm{As}, \mathrm{Mo}, \mathrm{Sn}$, and $\mathrm{Hg}$ were classified as moderately polluted. The mean $\mathrm{I}_{\text {geo }}$ values of $\mathrm{Al}, \mathrm{Li}, \mathrm{Co}$, and $\mathrm{Ti}$ were less than 1 for both the magnetic and non-magnetic road dust, indicating no contamination from these metals.

$\mathrm{Cr}$ is emitted from furnaces during the steel manufacturing process, and austenite stainless steel contains $18 \%$ of $\mathrm{Cr}[63,64]$. The high pollution status for $\mathrm{Cr}$ in the magnetic road dust was probably because metal particles from industrial activities, such as steel production and processing and the transportation process, accumulated on the road surface. The pollution levels of $\mathrm{Zn}, \mathrm{Cu}, \mathrm{Pb}$, and $\mathrm{Sb}$, which are highly related to traffic activities (e.g., the wear of brake pads and tires), were higher than the levels of other elements. In particular, Sb pollution was high in the non-magnetic road dust. The U.S. Environmental Protection Agency and the European Union were reported that Sb pollution is continuously increasing; $\mathrm{Sb}$ is designated as a class 1 carcinogen chemical and has a harmful effect on the environment and human health $[65,66]$. Brake pads contain about $1.5 \%$ of $\mathrm{Sb}$, and it has been reported that a vehicle emits $44 \mathrm{~g}$ of $\mathrm{Sb}$ per year $[67,68]$. The $\mathrm{Sb}$ concentrations in brake pads of Korea are 819-16,500 mg/kg, which is higher than that of the imported products [60]. According to Fiala and Hwang [69], the brake wear coefficient was $12.5 \mathrm{mg} / \mathrm{vehicle} / \mathrm{km}$ for a passenger car and $55 \mathrm{mg} /$ vehicle/ $\mathrm{km}$ for a heavy-duty vehicle, which showed an increase as the vehicle weight increased. Therefore, the metal contamination of road dust in this study is affected by steel manufacturing and processing as well as traffic activities by heavy-duty vehicles used for transporting raw materials and final products related to the steel industry. 
Table 3 shows the $\mathrm{E}_{\mathrm{r}}^{\mathrm{i}}$ values for 13 elements. In the magnetic road dust, the $\mathrm{E}_{\mathrm{r}}^{\mathrm{i}}$ decreased in the order of $\mathrm{Cd}>\mathrm{Hg}>\mathrm{Sb}>\mathrm{Pb}>\mathrm{Cr}>\mathrm{Cu}>\mathrm{Zn}>\mathrm{Ni}>\mathrm{Mn}>\mathrm{As}>\mathrm{Co}>\mathrm{V}>\mathrm{Ti}$. In particular, $\mathrm{Cd}$ and $\mathrm{Hg}$ pose an extreme risk, and $\mathrm{Sb}$ poses a high risk in both the magnetic and non-magnetic road dust. Our results indicate a considerable risk for $\mathrm{Cr}$ and $\mathrm{Pb}$ and a moderate risk for $\mathrm{Cu}$ and $\mathrm{Zn}$. The mean PERI values in the magnetic and non-magnetic road dust were 2975 and 1576, respectively. The magnetic road dust fell into the extreme ecological risk category (PERI > 600) at all sampling sites. Road dust for both magnetic and non-magnetic particles deposited on the road surface is resuspended by runoff and can accumulate in rivers and the marine environment, adversely affecting aquatic ecosystems. Therefore, a scientific approach is needed to reduce the metal pollution level of road dust and the adverse ecological risk.

Table 3. Comparison of mean $\mathrm{E}_{\mathrm{r}}^{\mathrm{i}}$ (ecological risk degree) values for 13 metals of this study.

\begin{tabular}{cccccc}
\hline Types & $\mathrm{E}_{\mathrm{r}}^{\mathbf{i}}<40$ & $40<\mathrm{E}_{\mathrm{r}}^{\mathbf{i}}<80$ & $80<\mathrm{E}_{\mathrm{r}}^{\mathbf{i}}<160$ & $160<\mathrm{E}_{\mathrm{r}}^{\mathbf{i}}<320$ & $\mathrm{E}_{\mathrm{r}}^{\mathbf{i}}>320$ \\
\hline Class & Low risk & Moderate risk & Considerable risk & High risk & Extreme risk \\
Magnetic road dust & $\mathrm{Ti}, \mathrm{V}, \mathrm{Mn}, \mathrm{Co}, \mathrm{Ni}, \mathrm{As}$ & $\mathrm{Cu}, \mathrm{As}$ & $\mathrm{Cr}, \mathrm{Pb}$ & $\mathrm{Cd}, \mathrm{Hg}$ & $\mathrm{Sb}$ \\
Non-magneticroad dust & $\mathrm{Ti}, \mathrm{V}, \mathrm{Cr}, \mathrm{Mn}, \mathrm{Co}, \mathrm{Ni}, \mathrm{Cu}, \mathrm{Zn}, \mathrm{As}$ & $\mathrm{Pb}$ & & $\mathrm{Cd}, \mathrm{Hg}$ \\
\hline
\end{tabular}

\subsection{Metal Loading in Magnetic and Non-Magnetic Road Dust from Steel Industrial Regions}

The total loading of the magnetic road dust was $298 \mathrm{~g} / \mathrm{m}^{2}$ (range: 79-805 g/m²) Even within an industrial area, the amount of road dust deposited on the road varied substantially among the sampling sites. The amount of road dust was affected by whether or not the road was cleaned and the effectiveness of the road cleaning. In Korea, unlike in residential areas, it is difficult to operate a road sweeper in an industrial area because there is insufficient parking space inside facilities, and illegal parking on the side of the road is commonplace. The mean total metal loading in the magnetic particles was $119 \mathrm{~g} / \mathrm{m}^{2}$ (range: $32-307 \mathrm{~g} / \mathrm{m}^{2}$ ). Fe accounted for about $81 \%$ on average, followed by $\mathrm{Al}>\mathrm{Mn}>\mathrm{Cr}>$ $\mathrm{Ti}>\mathrm{Zn}>\mathrm{Cu}>\mathrm{Pb}>\mathrm{Ni}>\mathrm{V}>\mathrm{Co}>\mathrm{Li}>\mathrm{Mo}>\mathrm{As}>\mathrm{Sb}>\mathrm{Sn}>\mathrm{Cd}>\mathrm{Hg}$ (Figure 3).

The total loading of the non-magnetic road dust was $410 \mathrm{~g} / \mathrm{m}^{2}\left(140-1114 \mathrm{~g} / \mathrm{m}^{2}\right)$ and was 1.4 times higher than that of the magnetic road dust on average. The total mean metal loading in the non-magnetic road dust was $50 \mathrm{~g} / \mathrm{m}^{2}$ (range: $15-190 \mathrm{~g} / \mathrm{m}^{2}$ ), which was $42 \%$ of the loading in the magnetic road dust. $\mathrm{Al}$ accounted for $58 \%$ of the metal loading in the total road dust. Fe accounted for $81 \%$ of the metal loading in the magnetic road dust, but in the non-magnetic road dust, the corresponding value was only $31 \%$.

Figure 3 shows the relative contribution of the metal loading $\left(\mathrm{mg} / \mathrm{m}^{2}\right)$ between the magnetic and non-magnetic road dust. There was a greater accumulation of $\mathrm{Fe}, \mathrm{V}, \mathrm{Cr}, \mathrm{Mn}$, $\mathrm{Co}, \mathrm{Ni}, \mathrm{Cu}, \mathrm{Zn}, \mathrm{Mo}, \mathrm{Cd}, \mathrm{Pb}$, and $\mathrm{Hg}$ in the magnetic road dust than in the non-magnetic road dust, while there was a greater accumulation of $\mathrm{Al}, \mathrm{Li}, \mathrm{Ti}, \mathrm{As}, \mathrm{Sn}$, and $\mathrm{Sb}$ in the non-magnetic road dust. The magnetic road dust accounted for $44.7 \%$ of the total road dust. The relative contributions of the metal loading in the magnetic fraction were $86 \%$ for $\mathrm{Fe}$, $77 \%$ for $\mathrm{Cr}, 67 \%$ for $\mathrm{Mn}, 86 \%$ for $\mathrm{Ni}, 76 \%$ for $\mathrm{Cu}, 73 \%$ for $\mathrm{Co}, 72 \%$ for $\mathrm{Zn}, 67 \%$ for $\mathrm{Hg}, 64 \%$ for Mo, $62 \%$ for $\mathrm{Cd}$, and $60 \%$ for $\mathrm{V}$.

Road dust is widely known to cause various diseases through exposure to atmospheric environments and the human body [70-74]. Because road cleaning is the most effective way to remove road dust polluted with various chemicals, many countries have introduced various types of road sweepers, such as road water spraying, mechanical brooms, vacuum systems, and regenerative air sweepers $[24,75,76]$. Metal contamination of road dust in industrial areas is largely influenced by industrial and traffic activities. Therefore, it is very difficult to trace and control the exact cause of metal contamination. Increasing the frequency of road cleaning will be the most effective way to reduce metal contamination from road dust and manage the environmental problems caused by contaminated road dust. However, due to the huge amounts of road dust removed from road surfaces, disposal can cause other environmental problems. 
a)

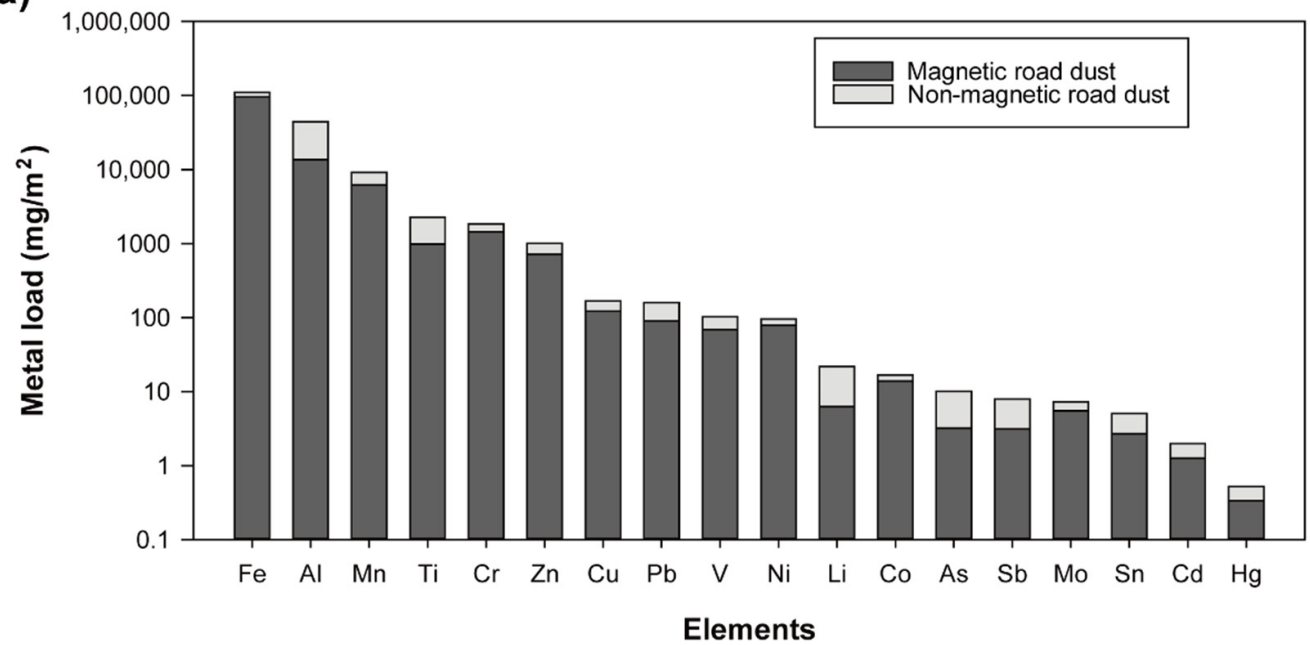

b)

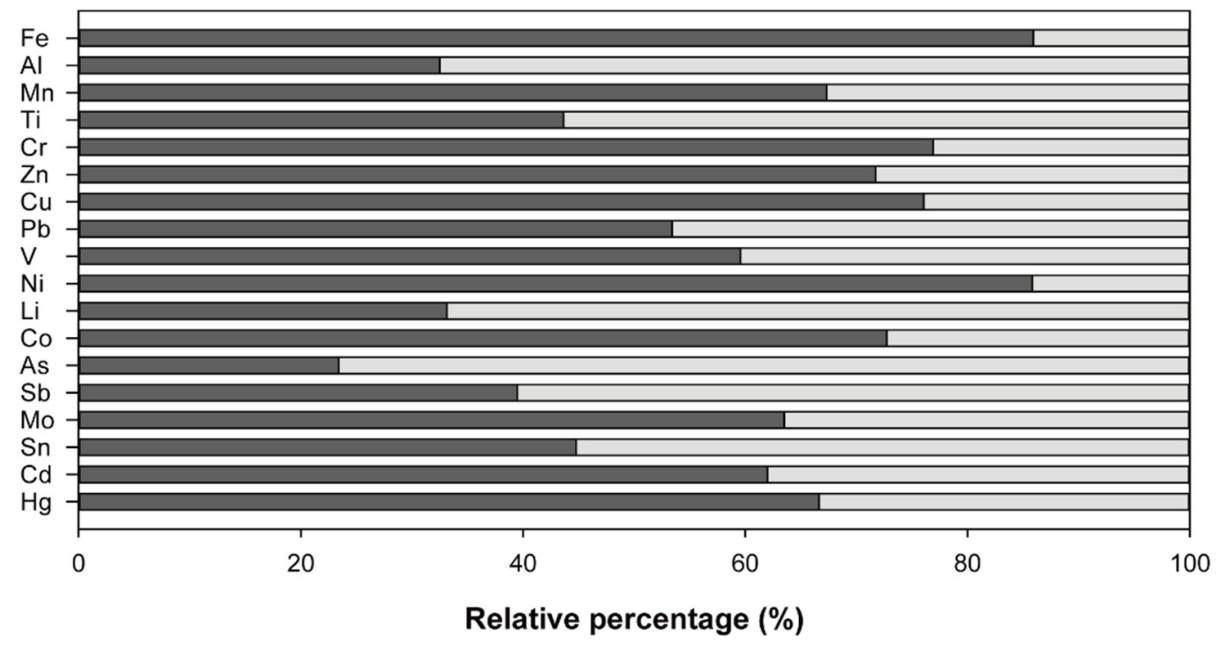

Figure 3. Comparison of mean metal loading $\left(\mathrm{mg} / \mathrm{m}^{2}\right)$ in magnetic and non-magnetic road dust (a) and relative contribution (\%) for 18 metals in magnetic and non-magnetic road dust (b) from steel industrial region of Korea.

Heavy metals, which are non-degradable and persistent pollutants, accumulate in soil, sediment, and road dust and contaminate many surrounding environments and organisms. Therefore, many remediation processes, such as chemical, physical, and biological treatments, are being used to improve metal contamination levels below regulatory and permissible limits by removing metal contamination from soils and sediments [77,78]. These processes can remove metal contamination, but problems such as efficiency and cost still exist when processing a large number of environmental samples.

Of course, it is also possible to selectively collect/remove magnetic road dust highly contaminated with toxic metals during road cleaning by developing a magnetic system with the road sweeper. Before sending the road dust periodically collected through the operation of a road sweeper to a waste treatment facility, using magnetic separation to send only magnetic road dust with high metal contamination to waste facilities can reduce the amount of waste and treatment costs and manage future environmental issues related to road cleaning strategy. Non-magnetic road dust, which accounts for about half of the total road dust, has a low level of metal contamination below the soil quality guideline values of Korea, so it will be possible to use it to create road infrastructures, including road pavement and rainwater drainage constructions.

The results of this study show that the metal pollution levels and loadings of the magnetic road dust were higher than in the non-magnetic road dust, and suggest that 
magnetic separation can reduce the amount of road dust as well as the levels of highly toxic metals. Therefore, it is necessary to determine how to effectively remove toxic metals during road cleaning and/or waste treatment after road cleaning.

\section{Conclusions}

In this study, most metals had higher concentrations in the magnetic fraction of road dust than in the non-magnetic fraction. As a result of the $I_{\text {geo, }}$ both the magnetic and nonmagnetic fractions were strongly to extremely polluted with $\mathrm{Sb}$. Regardless of magnetic separation, the ecological risk degrees $\left(\mathrm{E}_{\mathrm{r}}^{\mathrm{i}}\right)$ of $\mathrm{Sb}, \mathrm{Cd}$, and $\mathrm{Hg}$ were higher than the high risk. The magnetic fraction of road dust was in the extreme ecological risk category (PERI > 600) at all sampling sites. The accumulation of twelve metals ( $\mathrm{Fe}, \mathrm{V}, \mathrm{Cr}, \mathrm{Mn}, \mathrm{Co}, \mathrm{Ni}, \mathrm{Cu}, \mathrm{Zn}, \mathrm{Mo}$, $\mathrm{Cd}, \mathrm{Pb}$, and $\mathrm{Hg}$ ) was higher in the magnetic fraction of road dust than in the non-magnetic fraction. The metal load in the magnetic fraction of road dust accounted for up to $86 \%$ $(\mathrm{Fe})$, and $\mathrm{Cr}, \mathrm{Mn}, \mathrm{Ni}, \mathrm{Cu}, \mathrm{Co}, \mathrm{Zn}, \mathrm{Hg}, \mathrm{Mo}, \mathrm{Cd}$, and $\mathrm{V}$ accounted for more than $60 \%$. This study suggests that the application of magnetic separation in road dust can reduce metal contamination levels. Road dust removed from road surfaces contains high concentrations of hazardous metals and is classified as waste, so there is a high risk of becoming another environmental issue. Magnetic separation technology to remove the magnetic fraction from road dust could be an effective road cleaning strategy to reduce waste generation.

Supplementary Materials: The following supporting information can be downloaded at: https: / / www.mdpi.com/article/10.3390/su14020919/s1, Table S1: Correlation matrix for metals concentrations in magnetic road dust. Bold indicates that correlation is significant at the 0.05 level.

Author Contributions: Conceptualization, data curation, writing —original draft preparation, writingreview and editing, H.J. and K.R.; formal analysis, investigation, validation, H.J.; methodology, funding acquisition, project administration, resources, supervision, visualization, K.R. All authors have read and agreed to the published version of the manuscript.

Funding: This research was funded by the Korea Institute of Ocean Science and Technology (KIOST), grant number PE99912.

Institutional Review Board Statement: Not applicable.

Informed Consent Statement: Not applicable.

Data Availability Statement: All data for this study are available from the first or corresponding authors upon request.

Acknowledgments: We thank the anonymous reviewers for their valuable comments to improve our manuscript.

Conflicts of Interest: The authors declare no conflict of interest.

\section{References}

1. Zhang, W.; Dong, C.; Ye, L.; Ma, H.; Yu, L. Magnetic properties of coastal loess on the Midao islands, northern China: Implications for provenance and weathering intensity. Palaeogeogr. Palaeoclim. Palaeoecol. 2012, 333-334, 160-167. [CrossRef]

2. Hällberg, L.P.; Stevens, T.; Almqvist, B.; Snowball, I.; Wiers, S.; Költringer, C.; Lu, H.; Zhang, H.; Lin, Z. Magnetic susceptibility parameters as proxies for desert sediment provenance. Aeolian Res. 2020, 46, 100615. [CrossRef]

3. Ahn, H.; Lim, J.; Kim, S.W. Magnetic Properties of a Holocene Sediment Core from the Yeongsan Estuary, Southwest Korea: Implications for Diagenetic Effects and Availability as Paleoenvironmental Proxies. Front. Earth Sci. 2021, 9, 593332. [CrossRef]

4. Botsou, F.; Karageorgis, A.; Dassenakis, E.; Scoullos, M. Assessment of heavy metal contamination and mineral magnetic characterization of the Asopos River sediments (Central Greece). Mar. Pollut. Bull. 2011, 62, 547-563. [CrossRef] [PubMed]

5. Sierra, C.; Martínez-Blanco, D.; Blanco, J.A.; Gallego, J.; Rodríguez-Gallego, J.L. Optimisation of magnetic separation: A case study for soil washing at a heavy metals polluted site. Chemosphere 2014, 107, 290-296. [CrossRef] [PubMed]

6. Xia, D.; Wang, B.; Yu, Y.; Jia, J.; Nie, Y.; Wang, X.; Xu, S. Combination of magnetic parameters and heavy metals to discriminate soil-contamination sources in Yinchuan-A typical oasis city of Northwestern China. Sci. Total Environ. 2014, 485-486, 83-92. [CrossRef] [PubMed]

7. Yukumatsu, K.; Nomura, N.; Mishima, F.; Akiyama, Y.; Nishijima, S. Development of volume reduction method of cesium contaminated soil with magnetic separation. Prog. Supercond. Cryog. 2016, 18, 10-13. [CrossRef] 
8. Hong, H.P.; Kwon, H.W.; Kim, J.J.; Ha, D.W.; Kim, Y.H. Evaluation of contaminated for the Andong-dam sediments and a magnetic separation for reducing the contamination level. Prog. Supercond. Cryog. 2019, 21, 31-35. [CrossRef]

9. Pan, H.; Lu, X.; Lei, K.; Shi, D.; Ren, C.; Yang, L.; Wang, L. Using magnetic susceptibility to evaluate pollution status of the sediment for a typical reservoir in northwestern China. Environ. Sci. Pollut. Res. 2018, 26, 3019-3032. [CrossRef]

10. Ma, N.; Houser, J.B.; Wood, L.A.; Lewis, R.W.; Hill, D.G. Enhancement of Iron Recovery from Steelmaking Slag Fines by Process Optimization of Upgrading the Slag Fines with Dry Magnetic Separation. J. Sustain. Met. 2016, 3, 280-288. [CrossRef]

11. Iranmanesh, M.; Hulliger, J. Magnetic separation: Its application in mining, waste purification, medicine, biochemistry and chemistry. Chem. Soc. Rev. 2017, 46, 5925-5934. [CrossRef] [PubMed]

12. Lan, Y.-P.; Liu, Q.-C.; Meng, F.; Niu, D.-L.; Zhao, H. Optimization of magnetic separation process for iron recovery from steel slag. J. Iron Steel Res. Int. 2017, 24, 165-170. [CrossRef]

13. Chen, Y.; Cao, M.; Ma, C. Review of Coal-Fired Electrification and Magnetic Separation Desulfurization Technology. Appl. Sci. 2019, 9, 1158. [CrossRef]

14. Shibaeva, D.N.; Kompanchenko, A.A.; Tereschenko, S.V. Analysis of the Effect of Dry Magnetic Separation on the Process of Ferruginous Quartzites Disintegration. Minerals 2021, 11, 797. [CrossRef]

15. Ma, L.; Abuduwaili, J.; Liu, W. Spatial Distribution and Health Risk Assessment of Potentially Toxic Elements in Surface Soils of Bosten Lake Basin, Central Asia. Int. J. Environ. Res. Public Health 2019, 16, 3741. [CrossRef]

16. Huang, L.; Rad, S.; Xu, L.; Gui, L.; Song, X.; Li, Y.; Wu, Z.; Chen, Z. Heavy metals distribution, sources, and ecological risk assessment in Huixian wetland, South China. Water 2020, 12, 431. [CrossRef]

17. Jeong, H.; Choi, J.Y.; Lee, J.; Lim, J.; Ra, K. Heavy metal pollution by road-deposited sediments and its contribution to total suspended solids in rainfall runoff from intensive industrial areas. Environ. Pollut. 2020, 265, 115028. [CrossRef]

18. Jeong, H.; Choi, J.Y.; Lim, J.; Shim, W.J.; Kim, Y.O.; Ra, K. Characterization of the contribution of road deposited sediments to the contamination of the close marine environment with trace metals: Case of the port city of Busan (South Korea). Mar. Pollut. Bull. 2020, 161, 111717. [CrossRef]

19. Tong, S.; Li, H.; Wang, L.; Tudi, M.; Yang, L. Concentration, Spatial Distribution, Contamination Degree and Human Health Risk Assessment of Heavy Metals in Urban Soils across China between 2003 and 2019-A Systematic Review. Int. J. Environ. Res. Public Health 2020, 17, 3099. [CrossRef]

20. Goddu, S.R.; Appel, E.; Jordanova, D.; Wehland, F. Magnetic properties of road dust from Visakhapatnam (India)—-Relationship to industrial pollution and road traffic. Phys. Chem. Earth 2004, 29, 985-995. [CrossRef]

21. Gautam, P.; Blaha, U.; Appel, E. Magnetic susceptibility of dust-loaded leaves as a proxy of traffic-related heavy metal pollution in Kathmandu city, Nepal. Atmos. Environ. 2005, 39, 2201-2211. [CrossRef]

22. Larrasoaña, J.C.; Pey, J.; Zhao, X.; Heslop, D.; Mochales, T.; Mata, P.; Beamud, E.; Reyes, J.; Cerro, J.C.; Pérez, N.; et al Environmental magnetic fingerprinting of anthropogenic and natural atmospheric deposition over southwestern Europe. Atmos. Environ. 2021, 261, 118568. [CrossRef]

23. Bućko, M.S.; Magiera, T.; Johanson, B.; Petrovsky, E.; Pesonen, L.J. Identification of magnetic particulates in road dust accumulated on roadside snow using magnetic, geochemical and micro-morphological analyses. Environ. Pollut. 2011, 159, 1266-1276. [CrossRef]

24. Bourliva, A.; Papadopoulou, L.; Aidona, E. Study of road dust magnetic phases as the main carrier of potentially harmful trace elements. Sci. Total Environ. 2016, 553, 380-391. [CrossRef]

25. Tan, Z.; Lu, S.; Zhao, H.; Kai, X.; Jiaxian, P.; Win, M.S.; Yu, S.; Yonemochi, S.; Wang, Q. Magnetic, geochemical characterization and health risk assessment of road dust in Xuanwei and Fuyuan, China. Environ. Geochem. Health 2018, 40, 1541-1555. [CrossRef] [PubMed]

26. Jeong, H.; Lee, J.; Kim, K.-T.; Kim, E.-S.; Ra, K. Identification on Metal Pollution Sources in Road Dust of Industrial Complex Using Magnetic Property Around Shihwa Lake Basin. J. Korean Soc. Mar. Environ. Energy 2019, 22, 18-33. [CrossRef]

27. Jeong, H.; Choi, J.Y.; Ra, K. Potentially toxic elements pollution in road deposited sediments around the active smelting industry of Korea. Sci. Rep. 2021, 11, 7238. [CrossRef]

28. Jordanova, D.; Jordanova, N.; Lanos, P.; Petrov, P.; Tsacheva, T. Magnetism of outdoor and indoor settled dust and its utilization as a tool for revealing the effect of elevated particulate air pollution on cardiovascular mortality. Geochem. Geophys. Geosystems 2012, 13, Q08Z49. [CrossRef]

29. Liu, E.; Yan, T.; Birch, G.; Zhu, Y. Pollution and health risk of potentially toxic metals in urban road dust in Nanjing, a mega-city of China. Sci. Total Environ. 2014, 476-477, 522-531. [CrossRef]

30. Liu, H.; Yan, Y.; Chang, H.; Chen, H.; Liang, L.; Liu, X.; Qiang, X.; Sun, Y. Magnetic signatures of natural and anthropogenic sources of urban dust aerosol. Atmos. Chem. Phys. Discuss. 2019, 19, 731-745. [CrossRef]

31. Wang, J.; Li, S.-W.; Li, H.; Qian, X.; Li, X.; Liu, X.; Lu, H.; Wang, C.; Sun, Y. Trace metals and magnetic particles in PM2.5: Magnetic identification and its implications. Sci. Rep. 2017, 7, 9865. [CrossRef] [PubMed]

32. Khan, R.K.; Strand, M.A. Road dust and its effect on human health: A literature review. Epidemiol. Health 2018, 40, e2018013. [CrossRef]

33. Jordanova, D.; Jordanova, N.; Petrov, P. Magnetic susceptibility of road deposited sediments at a national scale-Relation to population size and urban pollution. Environ. Pollut. 2014, 189, 239-251. [CrossRef] 
34. Aguilera, A.; Morales, J.J.; Goguitchaichvili, A.; García-Oliva, F.; Armendariz-Arnez, C.; Quintana, P.; Bautista, F. Spatial distribution of magnetic material in urban road dust classified by land use and type of road in San Luis Potosí, Mexico. Air Qual. Atmos. Health 2020, 13, 951-963. [CrossRef]

35. Górka-Kostrubiec, B.; Magiera, T.; Dudzisz, K.; Dytłow, S.; Wawer, M.; Winkler, A. Integrated Magnetic Analyses for the Discrimination of Urban and Industrial Dusts. Minerals 2020, 10, 1056. [CrossRef]

36. Rutkowski, R.; Bihałowicz, J.S.; Rachwał, M.; Rogula-Kozłowska, W.; Rybak, J. Magnetic Susceptibility of Spider Webs and Dust: Preliminary Study in Wrocław, Poland. Minerals 2020, 10, 1018. [CrossRef]

37. Skorbiłowicz, M.; Skorbiłowicz, E.; Łapiński, W. Assessment of Metallic Content, Pollution, and Sources of Road Dust in the City of Białystok (Poland). Aerosol Air Qual. Res. 2020, 20, 2507-2518. [CrossRef]

38. Yang, D.; Wang, M.; Liu, J.; Deng, T.; Yan, C.; Ding, Z.; Lu, H. Occurrence and characteristics of iron-bearing minerals in surface road dusts: A case study in the coastal areas of southern Fujian, China. J. Soils Sediments 2020, 20, 3406-3416. [CrossRef]

39. Yang, D.; Wu, J.; Hong, H.; Liu, J. Traffic-related magnetic pollution in urban dust from the Xiamen Island, China. Environ. Chem. Lett. 2021, 19, 1-7. [CrossRef]

40. Tobin, G.A.; Brinkmann, R. The effectiveness of street sweepers in removing pollutants from road surfaces in Florida. J. Environ. Sci. Health Part A 2002, 37, 1687-1700. [CrossRef]

41. Tobin, G.A.; Brinkmann, R. Clean Streets-Clean Waterways: Street Sweeping, Storm-Water Runoff, and Pollution Reduction In World Minds: Geographical Perspectives on 100 Problems; Janelle, D.G., Warf, B., Hansen, K., Eds.; Springer: Dordrecht, The Netherlands, 2004. [CrossRef]

42. Rochfort, Q.; Exall, K.; P’Ng, J.; Shi, V.; Stevanovic-Briatico, V.; Kok, S.; Marsalek, J. Street Sweeping as a Method of Source Control for Urban Stormwater Pollution. Water Qual. Res. J. 2009, 44, 48-58. [CrossRef]

43. Amato, F.; Querol, X.; Johansson, C.; Nagl, C.; Alastuey, A. A review on the effectiveness of street sweeping, washing and dust suppressants as urban PM control methods. Sci. Total Environ. 2010, 408, 3070-3084. [CrossRef] [PubMed]

44. Kim, D.-G.; Jeong, K.; Ko, S.-O. Removal of road deposited sediments by sweeping and its contribution to highway runoff quality in Korea. Environ. Technol. 2014, 35, 2546-2555. [CrossRef] [PubMed]

45. Kim, D.-G.; Kim, H.-S.; Kang, H.-M.; Ko, S.-O. Pollutant characteristics of road deposited sediments collected by road sweeping. Water Sci. Technol. 2016, 74, 194-202. [CrossRef]

46. Calvillo, S.J.; Williams, E.S.; Brooks, B.W. Street Dust: Implications for Stormwater and Air Quality, and Environmental Management through Street Sweeping; Whitacre, D.M., Ed.; Reviews of Environmental Contamination and Toxicology; Springer International Publishing: Cham, Germany, 2015; Volume 233.

47. Vanegas-Useche, L.V.; Abdel-Wahab, M.M.; Parker, G.A. Effectiveness of oscillatory gutter brushes in removing street sweeping waste. Waste Manag. 2015, 43, 28-36. [CrossRef] [PubMed]

48. Lloyd, L.N.; Fitch, G.M.; Singh, T.S.; Smith, J.A. Characterization of Environmental Pollutants in Sediment Collected during Street Sweeping Operations to Evaluate its Potential for Reuse. J. Environ. Eng. 2018, 145, 04018141. [CrossRef]

49. Polukarova, M.; Markiewicz, A.; Björklund, K.; Strömvall, A.-M.; Galfi, H.; Sköld, Y.A.; Gustafsson, M.; Järlskog, I.; Aronsson, M. Organic pollutants, nano- and microparticles in street sweeping road dust and washwater. Environ. Int. 2019, 135, 105337. [CrossRef]

50. Muller, G. Index of geo-accumulation in sediments of the Rhine River. Geol. J. 1969, 2, 108-118.

51. Forstner, U. Inorganic sediment chemistry and elemental speciation. In Sediments: Chemistry and Toxicity on In-Place Pollutants; Baudo, P., Giesvand, J.P., Mantau, H., Eds.; CRC Press: Boca Raton, FL, USA, 1990; pp. 61-105.

52. Rudnick, R.L.; Gao, S. Composition of the continental crust. In Treatise on Geochemistry; Heinrich, D.H., Karl, K.T., Eds.; Pergamon: Oxford, UK, 2004; pp. 1-64.

53. Håkanson, L. An ecological risk index for aquatic pollution control: A sedimentological approach. Water Res. 1980, 14, 975-1001. [CrossRef]

54. Xu, Z.Q.; Ni, S.; Tuo, X.G.; Zhang, C.J. Calculation of heavy metal's toxicity coefficient in the evaluation of potential ecological risk index. Environ. Sci. Technol. 2008, 31, 112-115.

55. Wang, N.; Wang, A.; Kong, L.; He, M. Calculation and application of Sb toxicity coefficient for potential ecological risk assessment. Sci. Total Environ. 2018, 610-611, 167-174. [CrossRef]

56. Bućko, M.S.; Magiera, T.; Pesonen, L.J.; Janus, B. Magnetic, Geochemical, and Microstructural Characteristics of Road Dust on Roadsides with Different Traffic Volumes-Case Study from Finland. Water Air Soil Pollut. 2010, 209, 295-306. [CrossRef]

57. Kolakkandi, V.; Sharma, B.; Rana, A.; Dey, S.; Rawat, P.; Sarkar, S. Spatially resolved distribution, sources and health risks of heavy metals in size-fractionated road dust from 57 sites across megacity Kolkata, India. Sci. Total Environ. 2020, 705, 135805. [CrossRef]

58. Rahman, M.S.; Kumar, P.; Ullah, M.; Jolly, Y.N.; Akhter, S.; Kabir, J.; Begum, B.A.; Salam, A. Elemental analysis in surface soil and dust of roadside academic institutions in Dhaka city, Bangladesh and their impact on human health. Environ. Chem. Ecotoxicol. 2021, 3, 197-208. [CrossRef]

59. Mutuku, K.J.; Lee, Y.-Y.; Chang-Chien, G.-P.; Lin, S.-L.; Chen, W.-H.; Hou, W.-C. Chemical fingerprint for PM2.5 in the ambient air near a raw materials storage site for iron ore, coal, limestone, and sinter. Aerosol Air Qual. Res. 2021, 21, 200624. [CrossRef]

60. Jeong, H.; Ryu, J.-S.; Ra, K. Characteristics of potentially toxic elements and multi-isotope signatures $(\mathrm{Cu}, \mathrm{Zn}, \mathrm{Pb})$ in non-exhaust traffic emission sources. Environ. Pollut. 2021, 292, 118339. [CrossRef] 
61. Ministry of Government Legislation. Korea Soil Quality Standard of Heavy Metals in Soil Environment Conservation Act (Law No16613). 2019. Available online: https:/ / www.law.go.kr/ (accessed on 11 January 2022).

62. Jordanova, N.; Jordanova, D.; Tcherkezova, E.; Georgieva, B.; Ishlyamski, D. Advanced mineral magnetic and geochemical investigations of road dusts for assessment of pollution in urban areas near the largest copper smelter in SE Europe. Sci. Total Environ. 2021, 792, 148402. [CrossRef] [PubMed]

63. Wang, K.; Tian, H.; Hua, S.; Zhu, C.; Gao, J.; Xue, Y.; Hao, J.; Wang, Y.; Zhou, J. A comprehensive emission inventory of multiple air pollutants from iron and steel industry in China: Temporal trends and spatial variation characteristics. Sci. Total Environ. 2016, 559, 7-14. [CrossRef] [PubMed]

64. Sotoodeh, K. Chapter Twelve-Material selection and corrosion. Subsea Valves Actuators Oil Gas Ind. 2021, 421-457. [CrossRef]

65. Iijima, A.; Sato, K.; Yano, K.; Tago, H.; Kato, M.; Kimura, H.; Furuta, N. Particle size and composition distribution analysis of automotive brake abrasion dusts for the evaluation of antimony sources of airborne particulate matter. Atmos. Environ. 2007, 41, 4908-4919. [CrossRef]

66. Iijima, A.; Sato, K.; Yano, K.; Kato, M.; Kozawa, K.; Furuta, N. Emission Factor for Antimony in Brake Abrasion Dusts as One of the Major Atmospheric Antimony Sources. Environ. Sci. Technol. 2008, 42, 2937-2942. [CrossRef] [PubMed]

67. He, M.; Wang, X.; Wu, F.; Fu, Z. Antimony pollution in China. Sci. Total Environ. 2012, 421-422, 41-50. [CrossRef] [PubMed]

68. Li, J.; Zheng, B.; He, Y.; Zhou, Y.; Chen, X.; Ruan, S.; Yang, Y.; Dai, C.; Tang, L. Antimony contamination, consequences and removal techniques: A review. Ecotoxicol. Environ. Saf. 2018, 156, 125-134. [CrossRef]

69. Fiala, M.; Hwang, H.-M. Development of a Static Model to Identify Best Management Practices for Trace Metals from Non-Exhaust Traffic Emissions. Environ. Process. 2019, 6, 377-389. [CrossRef]

70. Kong, S.; Lu, B.; Ji, Y.; Zhao, X.; Bai, Z.; Xu, Y.; Liu, Y.; Jiang, H. Risk assessment of heavy metals in road and soil dusts within PM2.5, PM10 and PM100 fractions in Dongying city, Shandong Province, China. J. Environ. Monit. 2012, 14, 791-803. [CrossRef]

71. Amato, F.; Alastuey, A.; de la Rosa, J.; Castanedo, Y.G.; de la Campa, A.M.S.; Pandolfi, M.; Lozano, A.; González, J.C.; Querol, $X$. Trends of road dust emissions contributions on ambient air particulate levels at rural, urban and industrial sites in southern Spain. Atmospheric Chem. Phys. 2014, 14, 3533-3544. [CrossRef]

72. Ali, M.U.; Liu, G.; Yousaf, B.; Abbas, Q.; Ullah, H.; Munir, M.A.M.; Fu, B. Pollution characteristics and human health risks of potentially (eco)toxic elements (PTEs) in road dust from metropolitan area of Hefei, China. Chemosphere 2017, 181, 111-121. [CrossRef]

73. Cai, K.; Li, C. Street Dust Heavy Metal Pollution Source Apportionment and Sustainable Management in A Typical CityShijiazhuang, China. Int. J. Environ. Res. Public Health 2019, 16, 2625. [CrossRef]

74. Jiang, Y.; Ma, J.; Ruan, X.; Chen, X. Compound health risk assessment of cumulative heavy metal exposure: A case study of a village near a battery factory in Henan Province, China. Environ. Sci. Process. Impacts 2020, 22, 1408-1422. [CrossRef]

75. Donati, L.; Fontanini, T.; Tagliaferri, F.; Prati, A. An Energy Saving Road Sweeper Using Deep Vision for Garbage Detection. Appl. Sci. 2020, 10, 8146. [CrossRef]

76. Khan, J.; Bhapkar, U.; Bhat, J.; Chougule, A.; Sangale, S. Design and development of smart solar powered street sweeping machine. Mater. Today Proc. 2021, 46, 8663-8667. [CrossRef]

77. Peng, W.; Li, X.; Xiao, S.; Fan, W. Review of remediation technologies for sediments contaminated by heavy metals. J. Soils Sediments 2018, 18, 1701-1719. [CrossRef]

78. Selvi, A.; Rajasekar, A.; Theerthagiri, J.; Ananthaselvam, A.; Sathishkumar, K.; Madhavan, J.; Rahman, P.K.S. Integrated Remediation Processes Toward Heavy Metal Removal/Recovery From Various Environments-A Review. Front. Environ. Sci. 2019, 7, 66. [CrossRef] 